\title{
Nobility in the linguistic consciousness of Russians and Kazakhs
}

\author{
Gulzhana Kuzembayeva - Anargul Zhumakhanova - Marina Kulinich - \\ Vladimir Sinyachkin - Zhumagul Maydangalieva
}

DOI: 10.18355/XL.2019.12.04.03

\begin{abstract}
Of special interest is two-fold nature of the "nobility" concept, which includes both a noble origin and a high standing in society, as well as moral qualities of a person, and the fact that there is not a single word in the Kazakh language that exactly corresponds to the Russian word "nobility." The purpose of the study is to describe ways of conceptualizing nobility by speakers of different languages, modeling the associative field of the stimulus NOBILITY in the Russian and Kazakh languages, identifying similarities and differences in the conceptualization of nobility among representatives of the Russian and Kazakh cultures. The article presents the results of a psycholinguistic study, within the frame of which a mass associative experiment was conducted with groups of Russian and Kazakh respondents from the Russian Federation and the Republic of Kazakhstan. The obtained associative data were distributed according to the frequency criterion, followed by modeling the associative field and its cognitive structure. The common and specific components identified in the associative meaning to the stimulus NOBILITY are due to differences in the structures of languages and the ethnic specificity of the Russian and Kazakh cultures. While comparing associative fields in the Russian and Kazakhs languages, the quantitative asymmetry of semantic zones and their associates is revealed. The most voluminous semantic zone in both languages is that of moral personal qualities. The results of the study can be effective in further exploring of the linguistic consciousness and ethnic specificity of different nations, and cross-cultural research.
\end{abstract}

Key words: nobility, linguistic consciousness, ethnic specificity, the Russian language, the Kazakh language

\section{Introduction}

An anthropocentric paradigm that replaced systemic structural paradigm of humanitarian knowledge (Kubryakova, 1994) put into the focus the relationship between human perception of the external world and its language representation. Being part of a certain culture, including history, literature, language, and national traditions determine the specificity of a person's world perception and awareness of the external world as compared to that of representatives of other cultures (Tarman, Chigisheva, 2017). Language is a determinant of national consciousness, the foundation which generations of any national culture use ,to build the house ${ }^{\text {ee }}$ for their spirituality (Masalimova et al., 2019). The close connection of language and culture of an ethnic group determines the reflection of the semantic content of the words (Bubnova, Kazachenko, 2018). Psychological, linguistic, and social determinants are closely interconnected (Faizah, 2016). Scholars agree that semantic properties of words are both language-specific and culturally specific (Eilola, Havelka, 2010; Fraga, Padron, Comesaña, 2007; Soares et al., 2012; Söderholm et al., 2013).

The central topics of inquiry in modern linguistics (such as psycholinguistics, cultural linguistics, and sociolinguistics) are linguistic consciousness and the image of the world. The study of linguistic consciousness suggests that "in studying units of language and linguistic structures, their psychologically real content is revealed. That is, in what real, "psychologically authentic" set of semantic components a certain meaning exists in the consciousness of an ethnos, is stored in its linguistic memory; how the separate meaningful components which make up a word semantics are related 
in terms of "brightness" and relevance, what real semantic connections of words and structures are in the language memory of a person (Popova, Sternin, 2001).

Thus, one of the most effective methods for the study of linguistic consciousness is a psycholinguistic experiment, where a native speaker acts both as an informant, reporting on his command of the language, and as a person with his system of values and motives (Dzhambaeva, 2013).

\section{Literature Review}

A psycholinguistic approach to the study of linguistic consciousness and its national and cultural specificity is based on the concepts of association and the associative meaning of a word. Associations, inspired by unconscious layers of images, are able to simulate verbal memory and consciousness of an "average" native speaker. Consciousness constitutes the basis of language, i.e. it is a necessary precondition for language (Zlatev, 2008). Uncontrolled associations are symbolic or direct projection of internal content of consciousness. They represent the phenomenon of mass consciousness and are able to convincingly identify the national and cultural specificity of the images of consciousness of speakers of different language communities and cultures (Dmitryuk, 2011). Model of language consciousness of a person is explained by a set of associations (Karaulov, 2000), being "a logical link between two contents of consciousness (sensations, perceptions, thoughts, feelings, etc.) in the person's experience expressed in the fact that the appearance in the mind of one of contents entails the appearance of another" (Goroshko, 2006).

The method of a free-associative experiment allows us to reveal mental images of the external world inherent in representatives of a certain ethnic group. Therefore, an associative experiment is effective in defining "semantic links of words and linguistic stereotypes objectively existing in the psyche of a native speaker of the language," or, more generally, "specific features of mentality" (Arkhipova, 2011). Having gained recognition as an effective applied method of research, the associative experiment was born in psychological science, used to reveal the private world of an individual (Nielsen, Ingwersen, 1999). At present, it is considered to be a psycholinguistic method, widely used in sociology, computational linguistics, theory of communication, teaching of foreign languages, logic, political science, etc. (Mukhametzyanova, Shayakhmetova, 2014).

Data obtained from a free-associative experiment is to be comprehensively analyzed by defining the frequency ratio of reactions, i.e. lexical associations, and determining the core-periphery relationship between them. According to T. Nedashkivska and L. Kushmar, "associative field is a specific cognitive structure of the linguistic consciousness, which is involved in the forming of the conceptual picture of the world" (Nedashkivska, Kushmar, 2017). According to K. Church and P. Hanks (1990), the statistical results of an associative experiment can be used in "constraining the language model both for speech recognition and optical character recognition (OCR); providing disambiguation cues for parsing highly ambiguous syntactic structures such as noun compounds, conjunctions, and prepositional phrases; retrieving texts from large; enhancing the productivity of computational linguists in compiling lexicons of lexico-syntactic facts; enhancing the productivity of lexicographers in identifying normal and conventional usage" (Church, Hanks, 1990). The associative network, built as a result of mass associative experiments, reflects the systematic connections between its elements, and the comparison of the language picture of the world fragments, the model components allows to make conclusions on the discrepancy both between meanings of components and their systematicity (Ufimtseva, Balyasnikova, 2019).

From the above reasoning, we believe that the data obtained through a free-associative experiment can be interpreted as a consciousness reflection of representatives from

XLinguae, Volume 12, Issue 4, October 2019, ISSN 1337-8384, eISSN 2453-711X 
different cultures, and will reveal characteristics of linguistic consciousness and the national and cultural specificity of a particular ethnos.

The aim of our study is to describe ways of conceptualizing nobility by speakers of multi-structural languages and different cultures, modeling the associative field "nobility" in the Russian and Kazakh languages, and identifying similarities and differences in the conceptualization of nobility among representatives of Russian and Kazakh linguistic cultures.

The importance of the study is justified by all the above-mentioned reasons, also by the two-fold nature of the "nobility" concept, and the fact that there is not a single word in the Kazakh language exactly corresponding to the Russian word 'благородство' / nobility, or the English word 'nobility.' In this connection, it is interesting to explore and compare the concepts of nobility in the linguistic cultures of the Russian and Kazakh ethnic groups and to identify its ethnic specificity in the linguistic consciousness of native speakers of the Russian and Kazakh languages.

Attempts to probe into the concept of the nobility have been repeatedly made by such eminent thinkers as D. Alighieri (2002), F. Nietzsche (2002, 2006), R. Dilts (1998). The two principles of nobility, which are opposite to each other socially and ethically, imply high origin and/or position and high moral qualities of people. The nobility of man, according to European philosophers, presupposes high ethical and aesthetic criteria of behavior, spiritual values, a hierarchy of desires and goals, self-discipline and devotion to service.

Nobility is an extremely important notion for the representatives of the British ethnos is defined as "the group of people belonging to the aristocracy, highest social class in the country," "the quality of being noble in character," origin "noted, high born" (Oxford Dictionary).

In the Russian language, the word nobility/благородство originally meant "origin from a noble family" (Krylov, 2005), and then other meanings appeared: "good manifestations of the inner essence of a person", "following high moral principles", "looks, manners, elegance and grace, taste" (Dmitriev, 2003).

In the Kazakh language, there is no word incorporating all components of the word 'nobility' semantics in Russian or English, so this non-identity of languages led to the conduct of our research.

\section{Methods}

In order to identify the specter of images associated with the concept of nobility, a psycholinguistic study was conducted among Russians and Kazakhs. The method of obtaining data was a free-associative experiment with the registration of answers given to the verbal stimulus "nobility." The results are presented in the form of an associative field where we distinguish the nucleus, near, far, and outer periphery, compiled on the basis of frequency analysis of the respondents' reactions. By cognitive analysis of the associative field "nobility" in the Russian and Kazakh languages, semantic zones in its structure are distinguished. To determine the universal and specific components in the associative field "nobility," we used a comparative method for analyzing the experimental results obtained in the two languages.

\section{Results and Discussion}

Students from the Samara State University of Social Sciences and Education, Samara, Russia (SGSPU), and West Kazakhstan Marat Ospanov Medical University, Aktobe, the Republic of Kazakhstan (ZKMU) took part in the free-associative experiment. The parallel experiment was conducted in the two higher educational institutions in 
November 2018. Participants were speakers of Russian (students of SGSPU, Russia) and Kazakh (students of ZKMU, the Republic of Kazakhstan). The total number of respondents is 136 people aged 17-23 years, of which 46 respondents are Russians, and 90 respondents are Kazakhs.

The stimulus NOBILITY was offered orally. The respondents issued in writing the first associations with it that came to mind. The number of reactions was not limited.

Based on the frequency of lexical associations, the core (identified by reactions from more than $20 \%$ of subjects), the near periphery $(10 \%-20 \%)$, the far periphery $(<10 \%)$, and the outer periphery (individual associates) were determined.

In the course of the free-associative experiment with Russian respondents, we received 479 associative reactions, 196 of which are different (see Table 1).

Table 1: The associative field of the stimulus NOBILITY in the Russian linguistic consciousness

\begin{tabular}{|c|c|}
\hline $\begin{array}{l}\text { Core } \\
\text { more than } \\
20 \%\end{array}$ & $\begin{array}{l}\text { 'Честь' honour (58,57\%), ‘честность' honesty, 'рыцарь' knight }(43,48 \%) \text {, } \\
\text { 'помощь' aid (36,96\%), ‘достоинство' dignity (28,3\%), 'доброта' } \\
\text { kindness, 'поступок’ deed (23,9\%), 'отвага' courage }(21,7 \%) \text {. }\end{array}$ \\
\hline $\begin{array}{l}\text { Near } \\
\text { periphery } \\
10 \%-20 \%\end{array}$ & 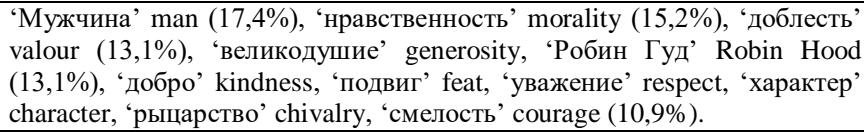 \\
\hline $\begin{array}{l}\text { Far periphery } \\
\text { less than } \\
10 \%\end{array}$ & 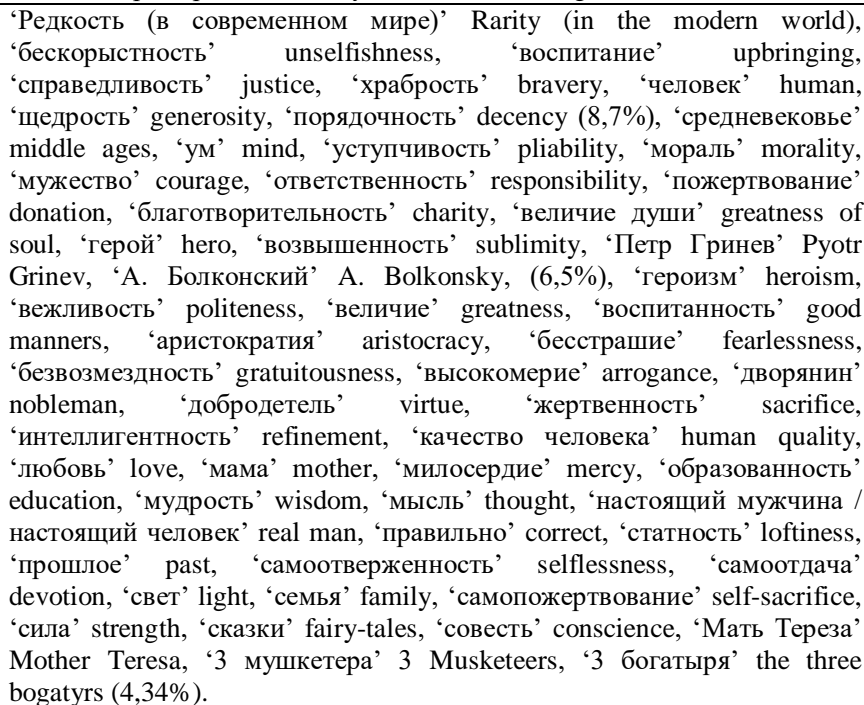 \\
\hline $\begin{array}{l}\text { Outer } \\
\text { periphery } \\
\text { Individual } \\
\text { associations }\end{array}$ & 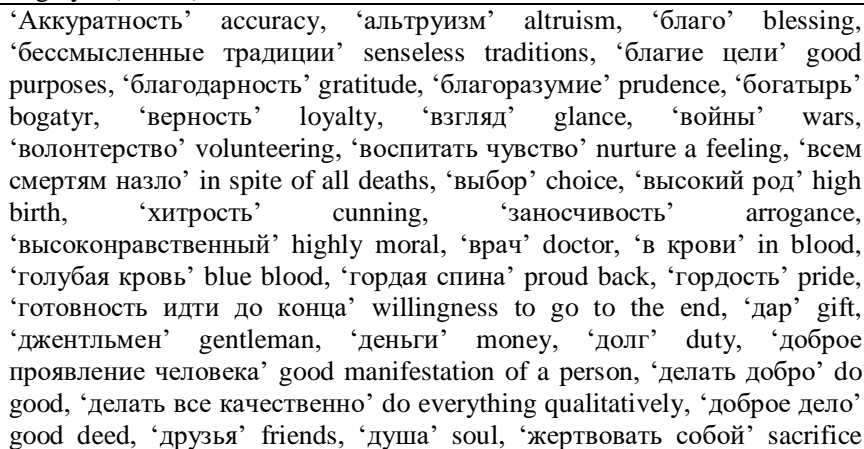 \\
\hline
\end{tabular}

XLinguae, Volume 12, Issue 4, October 2019, ISSN 1337-8384, eISSN 2453-711X 


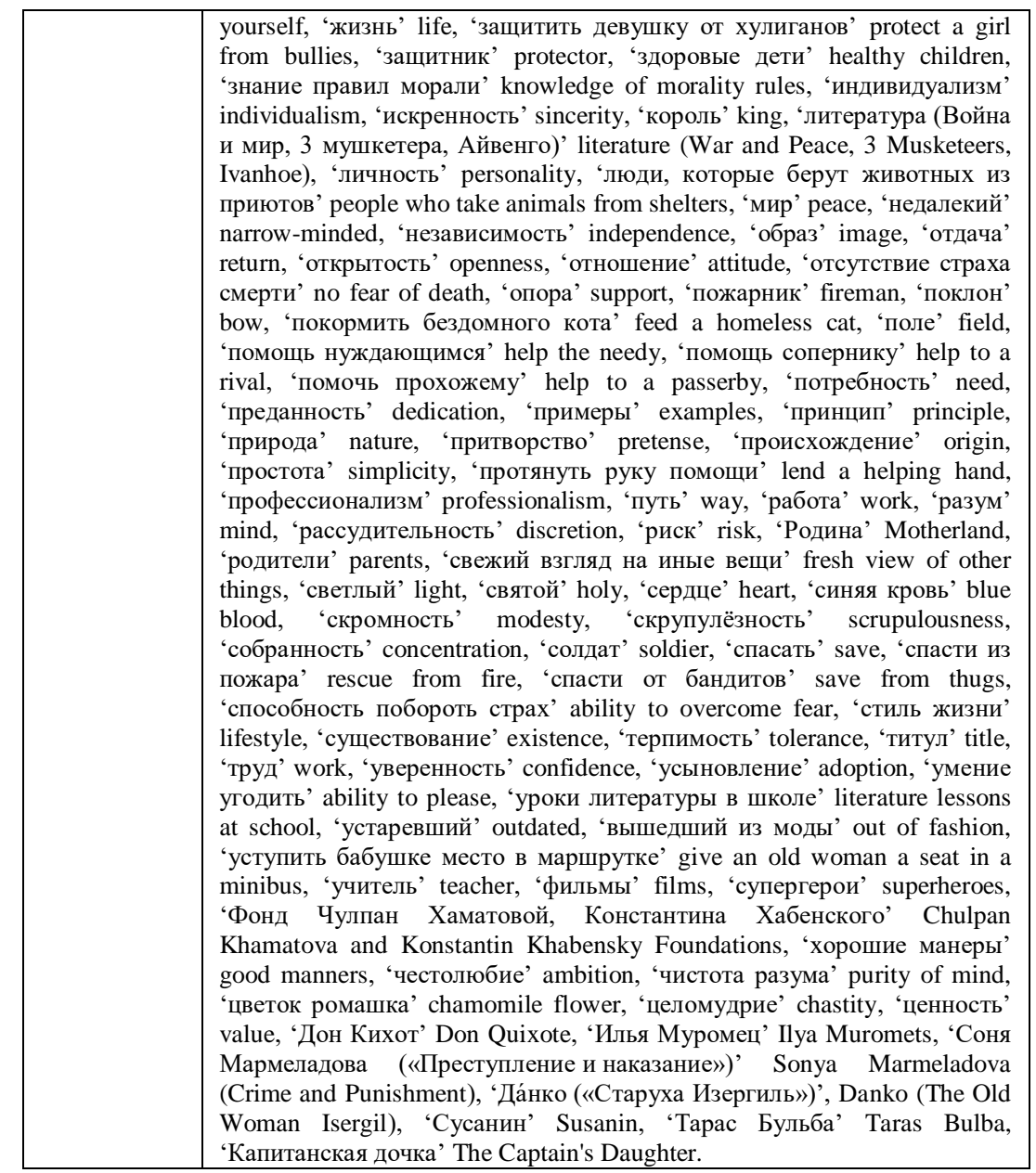

Source: authors

As a result of the cognitive analysis of the associative field "nobility" in the Russian language we distinguished the following semantic zones where the order of the components is determined by their number. Associations in semantic zones are given in decreasing order of their frequency:

Moral personality traits (честь / honour (27), честность / honesty (20), достоинство / dignity (13), доброта / kindness (11), нравственность / morality (7), великодушие / generosity (6), уважение / respect (5), характер / character (5), воспитание / upbringing (4), щедрость / generosity (4), порядочность / decency (4), справедливость / justice (4), уступчивость / pliability (3), величие души / greatness of soul (3), мораль / morality (3), ответственность / responsibility (3), вежливость / politeness (2), воспитанность / good manners (2), совесть / conscience (2), жертвенность / sacrifice (2), добродетель / virtue (2), качество человека / human quality (2), любовь / love (2), милосердие / mercy (2), аккуратность / accuracy, альтруизм / altruism, благоразумие / prudence, благодарность / gratitude, верность / loyalty, высоконравственный / highly moral, доброе проявление человека / good manifestation of a person, воспитать чувство / cultivate a feeling, долг / duty, индивидуализм / individualism, искренность / sincerity, независимость / 
independence, преданность / devotion, святой / holy, скромность / modesty, скрупулёзность / scrupulousness, собранность / concentration, терпимость / tolerance, уверенность / confidence, простота / simplicity, ценность / value, умение угодить / ability to please, открытость / openness, хорошие манеры / good manners, целомудрие / chastity);

Courage (отвага / courage (10), доблесть / valour (6), смелость / courage (5), храбрость / bravery (4), мужество / courage (3), герой / герой войны / hero / war hero (3), бесстрашие / fearlessness (2), самоотверженность / selflessness (2), героизм / heroism (2), ability to overcome fear / способность побороть страх, сила / strength, no fear of death / отсутствие страха смерти, in spite of all deaths / всем смертям назло);

Intelligence, education (ум / mind (3), мысль / thought (2), интеллигентность / culture (2), мудрость / wisdom (2), образованность / education (2), свет / light (2), правильно / correct (2), знание правил морали / knowledge of rules of morality, разум / mind, рассудительность / reasonableness, свежий взгляд на иные вещи / a fresh view of others things, светлый / light, opinion / взгляд, отношение / attitude, принцип / principle, профессионализм / professionalism, потребность / need, выбор / choice, делать все качественно / do everything qualitatively, чистота разума / purity of mind);

Deed (пожертвование / donation (32), помощь / aid (17), поступок / deed (11), добро / good (5), feat / подвиг (5), бескорыстность / unselfishness (4), благотворительность / charity (3), безвозмездность / gratuitousness (2), самоотдача / dedication (2), самопожертвование / self-sacrifice (2), отдача / return, уступить бабушке место в маршрутке / give an old woman a place in a minibus, спасать / save, спасти из пожара / rescue from fire, спасти от бандитов / save from thugs, покормить бездомного кота / feed a homeless cat, помощь нуждающимся / help the needy, помочь прохожему / help to a passerby, протянуть руку помощи / lend a helping hand, стиль жизни / lifestyle, существование / existence, усыновление / adoption, помощь сопернику / help to a rival, опора / support, поклон / bow, труд / work, благо / good, благие цели / good purposes, волонтерство / volunteering, готовность идти до конца / willingness to go to the end, делать добро / do good, доброе дело / good deed, защитник / protector, жертвовать собой / sacrifice yourself, защитить девушку от хулиганов / protect a girl from bullies);

Origin, position (рыцарь / knight (20), рыцарство / knighthood (5), возвышенность / sublimity (3), аристократия / aristocracy (2), величие / greatness (2), дворянин / nobleman (2), происхождение / origin, синяя кровь / blue blood, король / king, голубая кровь / (light) blue blood, высокий род / high birth, титул / title, в крови / in blood);

Appearance (статность / loftiness (2), гордая спина / proud back);

Time (редкость в современном мире / a rarity in the modern world (3), средневековье / the Middle Ages (3), прошлое / the past (2), устаревший / outdated, вышедший из моды / out of fashion);

Profession (учитель / teacher, пожарник / fireman, врач / doctor);

Subject (мужчина / man (8), человек / human (4), личность / personality, мама / mother (2), настоящий мужчина / настоящий человек / real man (2), семья / family (2), здоровые дети / healthy children, люди, которые берут животных из приютов / people who take animals from shelters, родители / parents, солдат / soldier, друзья / friends, джентльмен / gentleman, богатырь / bogatyr);

Object (сказки / fairy tales (2), уроки литературы в школе / literature lessons at school, Родина / Motherland, фильмы / films, супергерои / superheroes, фонд Чулпан Хаматовой, Константина Хабенского / Chulpan Khamatova, and Konstantin Khabensky foundations, цветок ромашка / chamomile flower,

XLinguae, Volume 12, Issue 4, October 2019, ISSN 1337-8384, eISSN 2453-711X 
литература (Война и мир, 3 мушкетера, Айвенго) / literature (War and Peace, 3 Musketeers, Ivanhoe), дар / gift, деньги / money, войны / wars, жизнь / life, мир / peace, душа / soul, образ / image, поле / field, природа / nature, путь / way, работа / work, риск / risk, сердце / heart, примеры / examples);

Characters (Робин Гуд / Robin Hood (6), Петр Гринев / Pyotr Grinev (3), А. Болконский / A. Bolkonsky (3), Мать Тереза / Mother Teresa (2), 3 мушкетера / 3 Musketeers (2), 3 богатыря / 3 Bogatyrs (2), Соня Мармеладова («Преступление и наказание» / Sonya Marmeladova (“Crime and Punishment”), Да́нко («Старуха Изергиль») / Danko (“The Old Woman Izergil”), Дон Кихот / Don Quixote, Илья Муромец / Ilya Muromets, Сусанин / Susanin, Тарас Бульба / Taras Bulba, Капитанская дочка / The Captain's Daughter);

Negative connotations (высокомерие / arrogance (2), честолюбие / ambition, притворство / pretense, недалекий / narrow-minded, гордость / pride, хитрость / cunning, заносчивость / arrogance, бессмысленные традиции / meaningless traditions).

The recorded reactions to the stimulus NOBILITY in the Kazakh language are 183 units, reduced to 41 associates, 16 of which are single (see Table 2).

Table 2: Associative field of the stimulus NOBILITY in the Kazakh linguistic consciousness

\begin{tabular}{|c|c|}
\hline Core & ‘Қайырымдылық’ mercy (31.1\%), ‘жақсылық’ kindness (20\%). \\
\hline $\begin{array}{l}\text { Near } \\
\text { periphery }\end{array}$ & $\begin{array}{l}\text { 'Мейірімділік' compassion, affection (15.6\%), 'көмек беру, қол ұшын } \\
\text { созу' aid, help (14,5\%), 'жомарттық' generosity (13,3\%), 'адамгершілік' } \\
\text { humanity }(11,1 \%) \text {, 'игі ic' good deed (10\%). }\end{array}$ \\
\hline $\begin{array}{l}\text { Far } \\
\text { periphery }\end{array}$ & 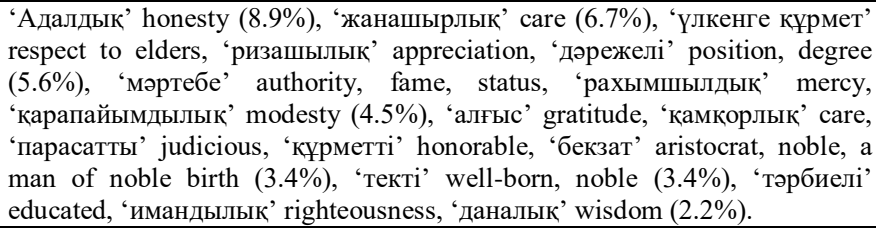 \\
\hline $\begin{array}{l}\text { Outer } \\
\text { periphery }\end{array}$ & 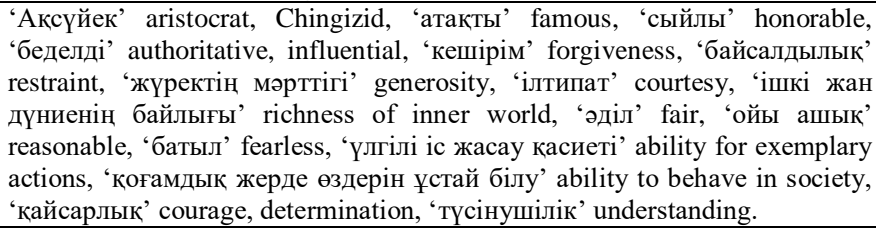 \\
\hline
\end{tabular}

Source: authors

The following zones are defined in the associative field "nobility" in the Kazakh language:

Moral personality traits (қайырымдылық / mercy (28), жақсылық / kindness (18), мейірімділік / compassion, affection (14), жомарттық / generosity (12), адамгершілік / humanity (10), адалдық / honesty (8), үлкенге құрмет / respect to elders (5), ризашылық / appreciation (5), алғыс / gratitude (3), рахымшылдық / mercy (4), қарапайымдылық / modesty (4), тәрбиелі / educated (2), имандылық / righteousness (2), кешірім / forgiveness, байсалдылық / restraint, жүректің мәрттігі / generosity, ілтипат / courtesy, ішкі жан дүниенің байлығы / richness of inner world, әділ / fair, түсінушілік / understanding);

Courage (батыл / fearless, қайсарлық / courage, determination);

Intelligence, education (парасатты / judicious (3), даналық / wisdom (2), ойы ашық / reasonable, үлгілі іс жасау қасиеті / ability for exemplary actions, қоғамдық жерде өздерін ұстай білу / ability to behave in society) 
Deed (көмек беру / aid, қол ұшын созу / help (13); игі ic / good deed (9), жанашырлық / care (6), қамқорлық / care (3);

Origin, position (дәрежелі / position, degree (5), мәртебе / authority, fame, status (4), құрметті / honorable (3), бекзат / aristocrat, noble, a man of noble birth (3), текті / well-born, noble (2), ақсүйек / aristocrat, Chingizid, атақты / famous, сыйлы / honorable, беделді / authoritative, influential).

Let us consider general and specific components in the structure of the semantic field "nobility" in the Russian and Kazakh languages. Among the semantic zones selected in Russian, the most voluminous are the Moral personality traits (34.03\%), Deed $(22.55 \%)$, Courage $(8.8 \%)$, and Origin, position $(8.56 \%)$. Consequently, in the Russian linguistic consciousness nobility implies high morality, good deeds, courage and reference to a noble origin.

Along with this, awareness of high position and greatness is rooted in people's minds and can manifest itself externally $(0.63 \%)$, as well as culture and education $(5.85 \%)$. Nobility includes characters of famous literary works, sacrificing themselves for the good of society and showing courage (5.4\%). Moreover, professions of teacher, doctor, fireman imply nobility too $(0.63 \%)$. Attention should be paid to the fact that negative components have also been identified in the semantics of nobility: arrogance, pride, haughtiness, etc. (1.88\%).

It follows from the obtained data that nobility in the Kazakh linguistic consciousness is objectified, first of all, by the moral personality traits $(66.7 \%)$, deeds $(16.94 \%)$ and high origin, position $(10.9 \%)$. In addition, the nobility of a person, according to the associative reactions of the Kazakh respondents, includes culture $(4.37 \%)$ and courage $(1.09 \%)$ (see Table 3$)$.

Table 3: General and specific components of nobility in the Russian and Kazakh linguistic consciousness

\begin{tabular}{|l|l|l|l|l|}
\hline \multirow{2}{*}{ Zones } & \multicolumn{2}{|l|}{ Russian } & Kazakh \\
\cline { 2 - 5 } & Quantity & $\%$ & Quantity & $\%$ \\
\hline Moral personality traits & 163 & 34,03 & 122 & 66,7 \\
\hline Deeds & 108 & 22,55 & 31 & 16,94 \\
\hline Courage & 42 & 8,8 & 2 & 1,09 \\
\hline Origin, position & 41 & 8,56 & 20 & 10,9 \\
\hline culture, education & 28 & 5,85 & 8 & 4,37 \\
\hline Fictional characters & 26 & 5,4 & - & - \\
\hline Subjects & 25 & 5,2 & - & - \\
\hline Objects & 22 & 4,59 & - & - \\
\hline Time & 9 & 1,88 & - & - \\
\hline Negative connotations & 9 & 1,88 & - & - \\
\hline Profession & 3 & 0,63 & - & - \\
\hline Appearance & 3 & 0,63 & - & - \\
\hline Total & 479 & 100 & 183 & 100 \\
\hline Source: auth & & & & \\
\hline
\end{tabular}

Source: authors

\section{Conclusions}

We believe that this psycholinguistic (free-associative) experiment aimed at identifying the semantics of the word 'nobility' in the minds of representatives of the Russian and Kazakh ethnic groups, is a valuable source of information and an effective tool for determining the content of concepts in different-structured, nonidentical languages. It is also efficient in studying ethnical specificity of nations, contributing to understanding and successful intercultural interaction between representatives of different linguocultures.

The associative experiment showed that 'nobility' in Russian has an extensive associative field (479 reactions), which proves its importance for the Russian 
linguistic consciousness. A number of individual reactions testify to the significant role of the subjective perception of nobility by native speakers of Russian. The significantly smaller amount of the associative field "nobility" in the linguistic consciousness of the Kazakhs speakers (183 reactions) is explained by the complexity of defining the semantics of the word 'nobility,' which has no equivalent in the Kazakh language.

The associative field in both languages is divided into meaningful zones without the remainder. The associative field "nobility" in the Russian language has 12 semantic zones that characterize various aspects of understanding nobility by representatives of the Russian ethnos: "moral personality traits", "deeds", "courage", "origin, position", "intelligence, education", "characters", "subject", "object", "time", "negative connotations", "profession", "appearance". In the Kazakh language, the associative field is formed of 5 semantic zones: "moral personality traits," "deeds," "origin, position," "culture, education," "courage," which are common for both languages. When comparing two associative fields, the quantitative asymmetry of semantic zones and their associates is noteworthy. The most voluminous semantic zone in the associative field "nobility" in two languages is the group that includes moral qualities of a person. The most prominent components of this zone in the Russian language is honour (16.6\%), honesty (12.3\%), dignity (7.98\%), and in Kazakh “қайырымдылық” / mercy (22.95\%), жақсылық / kindness (14.76\%), мейірімділік / compassion, affection (11.48\%), жомарттық / generosity (9.8\%), адамгершілік / humanity (8.2\%).

Thus, 'nobility' in linguistic consciousness of speakers of the Russian and Kazakh languages is, in the first place, objectified by moral qualities, good deeds, daring, and denotes high position or origin as well.

\section{Bibliographic references}

ALIGHIERI, D. 2002. Pir. Tractates. Available online: http://lib.ru/POEZIQ/DANTE/pir01.txt.

ARKHIPOVA, S.V. 2011. Associative experiment in psycholinguistics. In: Journal of Buryat State University. Language. Literature. Culture, vol. 11, pp. 6-9. ISBN: 2305459X.

BUBNOVA, I. - KAZACHENKO, O. 2018. Dynamics of the Semantic Content of the Word Freedom. Psycholinguistics, vol. 23, no. 2, pp. 11-24. ISSN 2309-1797.

CHURCH, K. - HANKS, P. 1990. Word Association Norms, Mutual Information, and Lexicography. In: Computational Linguistics, vol. 16, no. 1, pp. 241-257. DOI: $10.3115 / 981623.981633$.

DILTS, R. 1998. Strategies of geniuses. Tom 1. Aristotel', Sherlok Holms, Uolt Disnej, Vol'fgang Amadei Mocart. Moscow: Nezavisimaja firma «Klass». ISBN: 586375-071-5

DMITRIEV, D.V. 2003. Explanatory Dictionary of the Russian language. Moscow: Astrel'. ISBN: 421142

DMITRYUK, N.V. 2011. Free associative experiment as means of language consciousness investigation. In: Journal of Sh. Ualikhanov Kokshetau State University. Series "Philology", vol. 3, no. 1, pp. 81-86. ISBN 1608-2206.

DZHAMBAEVA, ZH.A. 2013. Associative experiment. Available online: http://repository.enu.kz/bitstream/handle/data/9683/Associativnyi-experiment.pdf.

EILOLA, T.M. - HAVELKA, J. 2010. Affective norms for 210 British English and Finnish nouns. In: Behavior Research Methods, vol. 42, pp. 134-140. ISSN: 1554351X (Print), 1554-3528 (Electronic), 1554-351X (Linking).

FAIZAH, S.A. 2016. Psycholinguistic determinants of immigrant second language acquisition. In: Lingua, vol. 179, pp. 24-37. ISSN: 0024-3841. 
GOROSHKO, E.I. 2006. Yazykovoye soznaniye: Gendernaya paradigma. SaintPetersburg: Aleteyya. ISBN: 2241-425.

KARAULOV, Y.N. 2000. Pokazateli natsionalnogo mentaliteta v assotsiativnoverbalnoyseti. Yazykovoye soznaniye i obraz mira, vol. 1, pp. 191-206. ISSN: 1774$301 X$.

KUBRYAKOVA, E.C. 1994. Paradigms of scientific knowledge in linguistics. In: Journal of Academy of Science. Series "Literature and language", vol. 2, pp. 3-15. ISSN 0321-1711.

KRYLOV, G.A. 2005. Etymological Dictionary of the Russian Language. St.Petersburg: Poligrafuslugi. ISBN 144-4257.

MASALIMOVA, A.R. - KORZHUEV, A.V. - VASBIEVA, D.G. - GALUSHKIN, A.A. - MAYDANGALIEVA, ZH.A. - ZAITSEVA, N.A. 2019. Philosophical View on Preservation of National Languages as A Factor of National Security in the Contemporary World. In: European Journal of Science and Theology, vol. 15, no. 2, pp. 113-121. ISSN: 1841-0464.

MUKHAMETZYANOVA, L. - SHAYAKHMETOVA, L. 2014. Application of Associative Experiment in Forming the Foreign Communicative Competence. English Language Teaching, vol. 7, no. 12. ISSN 1916-4742, E-ISSN 1916-4750.

NEDASHKIVSKA, T. - KUSHMAR, L. 2017. Associative Way from Perception to Understanding: Associative Field vs Lexical-Semantic Field. In: Journal of Modern Education Review, vol. 7, no. 1, pp. 44-50. ISSN: 2155-7993.

NIELSEN, M.L. - INGWERSEN, P. 1999. The word association methodology - a gateway to work-task based retrieval. Available online: https://www.bcs.org/upload/pdf/ewic_mi-99_paper6.pdf

NIETZSCHE, F. 2002. Beyond Good and Evil. Available online: http://www.holybooks.com/wp-content/uploads/Nietzsche-Beyond-Good-and-

Evil.pdf

NIETZSCHE, F. 2006. On the genealogy of morality. Cambridge: Univ. Press. ISBN 154-7585.

NOBILITY. 2019. Oxford Dictionaries. Available online: https://en.oxforddictionaries.com/definition/nobility

POPOVA, Z.D., - STERNIN, I.A. 2001. Sketches on cognitive linguistics. Voronezh: Istoki. ISBN 164-4882.

FRAGA, R.J. - PADRON, I.I. - COMESANA, M. 2007. The Spanish adaptation of ANEW (Affective Norms for English Words). In: Behavior Research Methods, vol. 39, pp. 600-605. ISSN: 1554-3528.

SOARES, A.P. - COMESANA, M. - PINHEIRO, A.P. - SIMÕES, A. - FRADE, C.S. 2012. The adaptation of the Affective Norms for English Words (ANEW) for European Portuguese. In: Behavior Research Methods, vol. 44, pp. 256-69. ISSN: $1554-3528$.

SODERHOLM, C. - HAYRY, E. - LAINE, M. - KARRASCH, M. 2013. Valence and Arousal Ratings for 420 Finnish Nouns by Age and Gender. Available online: https://doi.org/10.1371/journal.pone.0072859

TARMAN, B. - CHIGISHEVA, O. 2017. Transformation of educational policy, theory and practice in post-soviet social studies education. In: Journal of Social Studies Education Research, vol. 8, no. 2, pp. 1-4. ISSN:1309-9108.

UFIMTSEVA, N.V. - BALYASNIKOVA, O.V. 2019. Language Picture of the World and Associative Lexicography. In: Science Journal of VolSU. Linguistics, vol. 18, no. ISSN 1998-9911, ISSN 2409-1979.

Words: 5198

Characters: 37264 (20,70 standard pages)

XLinguae, Volume 12, Issue 4, October 2019, ISSN 1337-8384, eISSN 2453-711X 
Gulzhana Kuzembayeva, PhD

Languages Department

West Kazakhstan Marat Ospanov Medical University

Maresyev st, 68

030019 Aktobe

Kazakhstan

kuzembayeva@mail.ru

Anargul Zhumakhanova

Department of Foreign Philology

Eurasian National University named after L.N. Gumilyov

Satpayev st, 2

010008 Nur-Sultan

Kazakhstan

anargulja80@mail.ru

Marina Kulinich, Dr.

Samara State University of Social Sciences and Education

Department of English Philology and Intercultural Communication

M. Gorkogo st, 65/67

443099 Samara

Russia

marina-kulinich@yandex.ru

Vladimir Sinyachkin, Dr.

Department of Russian Language and Intercultural Communication

RUDN University- Peoples' Friendship University of Russia

Miklukho-Maklay st, 6

117198 Moscow

Russia

sinyachkin-vp@rudn.ru

Zhumagul Maydangalieva, PhD

Department of Pre-School Education and Primary Education

Baishev University Aktobe

Br. Zhubanovih st, 302a

030000 Aktobe

Kazakhstan

maydangalieva@mail.ru 